\title{
Role of Granulosa and Theca Cells on in Vitro Progesterone Production in Preovulatory Follicles of the Japanese Quail
}

\author{
Makoto Mori, Kaoru Koнmoto and Yoichi ShodA \\ Department of Animal Breeding, Faculty of Agriculture, University of \\ Tokyo, Bunkyo-ku, Tokyo 113, Japan
}

\section{Introduction}

The preovulatory follicles of the mature domestic birds are arranged in a distinct hierarchical order in the ovary. Presumably all preovulatory follicles are exposed to a daily surge of luteinizing hormone (LH), but only the largest follicle (F1) ovulates each day. This has been explained by the ability of progesterone synthesis of F1 in response to LH. In fact, progesterone contents in the follicle wall of $\mathrm{F} 1$, but not of the second largest (F2) or the third largest (F3) follicle, increased concomitantly with the raise of serum $\mathrm{LH}^{1,2}$. Even though the concentrations of $\mathrm{LH}$ were not significantly different among venous plasma of various sizes of follicles, only the venous plasma of F1 exhibited the preovulatory peak of progesterone ${ }^{3)}$. The ovulation was blocked by an injection of a steroid synthesis inhibitor, aminoglutethimide phosphate, and it could be overcome by an injection of progesterone ${ }^{4}$. All of these observations support the idea that progesterone synthesis in the follicle wall of F1 after LH surge is associated with the ovulation.

From the in vitro incubation studies, the cellular source of progesterone in chicken follicles has been shown to be the granulosa cells ${ }^{5}$. However, progesterone was synthesized not only by the granulosa cells of F1 but also by those of smaller follicles when LH was added to the incubation medium ${ }^{5,6.7)}$. No systematic experiments have yet been done which allow one to explain the discrepancy between in vivo and in vitro studies. Therefore, the present study was conducted to elucidate the role of the granulosa cells and the theca cells isolated from various sizes of follicles for progesterone sythesis in the quail ovary.

\section{Materials and Methods}

\section{Animals}

Laying Japanese quail (Coturnix coturnix japonica), 9 to 18 weeks of age, were used in the experiments. The birds, caged individually, were provided with food and water ad libitum. The lighting schedule was $14 \mathrm{~L}: 10 \mathrm{D}$ with lights on at 0500 . Time of oviposition of all birds was checked daily at $0.5-\mathrm{hr}$ intervals. The time of ovulation was predicted based on the time of oviposition of the previously ovulated follicle which usually occurred 15 to $30 \mathrm{~min}$ prior to the next ovulation ${ }^{8}$. 


\section{Tissue preparation}

The birds were killed with a guillotine. Three largest preovulatory follicles were collected at 9 to $10 \mathrm{hr}$ before the expected time of ovulation of F1, when serum LH concentrations and follicular progesterone contents were low ${ }^{2,9}$, and placed in ice-cold physiological saline. For preparation of the intact follicle wall, deep cuts into the yolk mass were made with fine scissors along the direction of the stigma and at the right angle to it. The follicle wall was then washed carefully with a mild stream of saline from a Pasteur pipette in order to remove adherent yolk on the wall. Thus, approximately four equal pieces of the follicle wall which consisted of the theca and granulosa layers can be obtained without contamination of the yolk.

For preparation of granulosa cells, the granulosa layers were isolated according to the procedure of GILBERT et al. ${ }^{10)}$ as modified by Kotosai11) for quail, and were weighed and dispersed by incubating with $500 \mathrm{U} / \mathrm{m} l$ collagenase (Type I, Sigma, St. Louis, MO) in 1.0 $\mathrm{ml}$ of incubation buffer (Krebs-Ringer-HEPES containing $0.4 \%$ D-glucose and $0.1 \%$ bovine serum albumin, $\mathrm{pH}$ 7.4). During digestion in a polystyrene tube, the content was frequently aspirated and expelled with a Pasteur pipette. After $10 \mathrm{~min}$ of incubation at $37^{\circ} \mathrm{C}$, the cells were collected by centrifugation at $800 \times \mathrm{g}$ for $3 \mathrm{~min}$. The precipitate was then washed three times with $3 \mathrm{ml}$ of the incubation buffer in order to remove collagenase. The final pellet derived from $10 \mathrm{mg}$ wet weight of the original tissue was resuspended in $1.0 \mathrm{ml}$ of the incubation buffer.

For preparation of the cell-free homogenates of theca layer, the theca layers were isolated according to the procedure of GILBERT et al. ${ }^{10)}$ and were homogenized in 50 volumes of the incubation buffer by using a motor-driven glass-galss homogenizer. The homogenates were centrifuged at $1,000 \times \mathrm{g}$ for $10 \mathrm{~min}$ at $4^{\circ} \mathrm{C}$ and the supernatant fluid was employed as the cell-free homogenates.

\section{Incubation condition}

A piece of follicle wall ( 8 to $20 \mathrm{mg}$ wet weight) was incubated in $1.0 \mathrm{~m} l$ of the incubation buffer at $40^{\circ} \mathrm{C}$ in air with constant shaking. The suspension of dispersed granulosa cells derived from $1 \mathrm{mg}$ wet weight of the tissue was also incubated in $1.0 \mathrm{ml}$ of the incubation buffer at $40^{\circ} \mathrm{C}$ in air with constant shaking. In some experiments, the incubation buffer contained $2 \mu \mathrm{g} / \mathrm{ml}$ ovine LH (NIAMDD-oLH-23) or $1 \mathrm{mM} \mathrm{N}^{6}, \mathrm{O}^{2}$-dibutyryladenosine 3 ':5'-cyclic monophosphate (dibutyryl cyclic AMP).

\section{Radioimmunoassay of progesterone}

Incubation was stopped by quick freezing at $-80^{\circ} \mathrm{C}$, and the tubes were kept at the same temperature until the radioimmunoassay of progesterone was performed. After thawing, whole contents were homogenized in a glass-glass homogenizer and steroids were extracted three times with $1.0 \mathrm{~m} l$ each of water-saturated diethyl ether. The pooled extract was then evaporated to dryness and subjected to the radioimmunoassay of progesterone without further purification. Progesterone antiserum was generously supplied by Dr. Michio Takahashi, Department of Veterinary Physiology, University of Tokyo, and $\left[1,2,6,{ }^{7}{ }^{3} \mathrm{H}(\mathrm{N})\right]$ progesterone was perchased from New England Nuclear Corp., Boston, MA, U.S.A. Protein was quantified by the method of Lowry et al. ${ }^{12)}$ using bovine serum albumin as the standard. 


\section{Results}

In order to investigate effects of $\mathrm{LH}$ and dibutyryl cyclic AMP on in vitro progesterone synthesis in quail follicles, the follicle walls of F1, F2, and F3 were incubated with or without LH or dibutyryl cyclic AMP for $3 \mathrm{hr}$. Fig. 1 shows that only follicle wall of F1 responded to $\mathrm{LH}$ and dibutyryl cyclic AMP to produce progesterone. The follicle walls of F2 and F3 did not produce progesterone during $3 \mathrm{hr}$ of incubation in the absence or the presence of LH or dibutyryl cyclic. AMP. The follicle walls of F1, which contained initially more progesterone than those of F2 or F3, produced a significant amount of progesterone during 3 $\mathrm{hr}$ of incubation in the absence of LH or dibutyryl cyclic AMP. Addition of LH or dibutyryl cyclic AMP caused further increase in progesterone production.

Progesterone synthesis in the isolated granulosa cells of F1, F2 and F3 are shown in Fig. 2. In contrast to the similar experiment using the intact follicle walls, the isolated granulosa cells of F2 and F3 produced significant amounts of progesterone during $3 \mathrm{hr}$ of incubation. However, in this case, progesterone production was observed in the control incubation and it was not significantly stimulated by the addition of $\mathrm{LH}$ or dibutyryl cyclic AMP. The responses of the granulosa cells of F1 to LH and dibutyryl cyclic AMP were not different from those of the follicle wall of $\mathrm{F} 1$.

Since the results shown in Figs. 1 and 2 strongly suggest that the granulosa cells of F2 and F3 have the ability of synthesizing progesterone, but the theca layer, another component of the follicle wall, may metabolize it, further experiments were carried out to delineate the differences of progesterone metabolic rates of the theca layers among the follicles. When the cell-free homogenates $(720 \mu \mathrm{g}$ protein $/ \mathrm{ml})$ of the theca layers obtained from $\mathrm{F} 1, \mathrm{~F} 2$, and F3 were incubated with progesterone $(100 \mathrm{ng} / \mathrm{ml})$ in the presence of NADPH, more than $90 \%$ of progesterone was metabolized after $3 \mathrm{hr}$ (Table 1). When the concentration of progesterone was increased to $1 \mu \mathrm{g} / \mathrm{ml}$ and the protein concentration of the cell-free homogenates

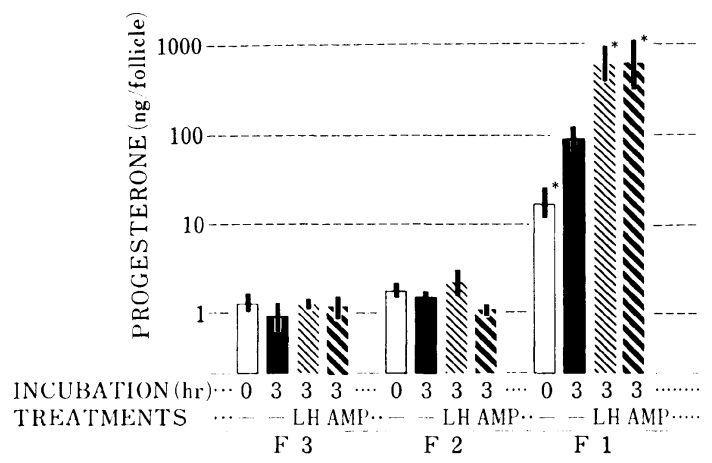

Fig. 1. Progesterone synthesis of the intact follicle walls of F1, F 2 and F 3 of the quail ovary. The follicle walls were incubated for $3 \mathrm{hr}$ at $40^{\circ} \mathrm{C}$ in the presence or the absence of $2 \mu \mathrm{g} / \mathrm{ml}$ ovine LH or $1 \mathrm{mM}$ dibutyryl cyclic AMP (AMP). Values, expressed as $\mathrm{ng} /$ follicle, are geometric mean \pm S.E. of four independent experiments.

* $\mathrm{P}<0.05$ against the control incubation in the absence of $\mathrm{LH}$ or dibutyryl cyclic AMP. 


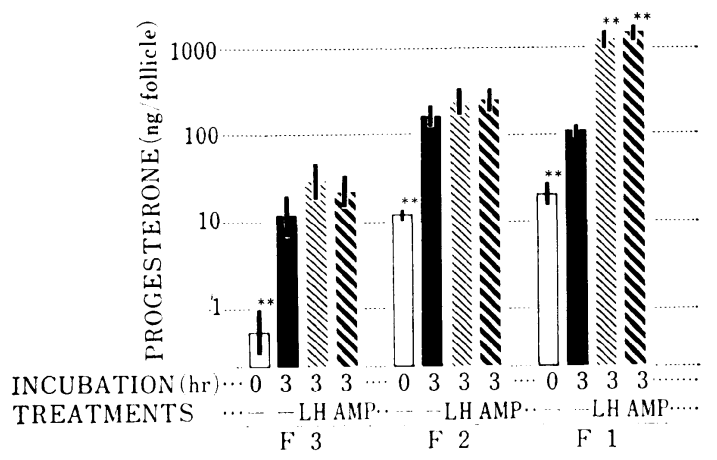

Fig. 2. Progesterone synthesis of the isolated granulosa cells of F 1, $\mathrm{F} 2$, and $\mathrm{F} 3$ of the quail ovary. The granulosa cells were incubated for $3 \mathrm{hr}$ at $40^{\circ} \mathrm{C}$ in the presence or the absence of 2 $\mu \mathrm{g} / \mathrm{m} l$ ovine $\mathrm{LH}$ or $1 \mathrm{mM}$ dibutyryl cyclic AMP (AMP). Values, expressed as $\mathrm{ng} /$ follicle, are geometric mean $\pm \mathrm{S}$. E. of four independent experiments.

** $\mathrm{P}<0.01$ against the control incubation in the absence of $\mathrm{LH}$ or dibutyryl cyclic AMP.

Table 1. Decrease of progesterone by the cell-free homogenates of the theca layer

The cell-free homogenates of the theca layer were incubated with progesterone $(100 \mathrm{ng} / \mathrm{m} l$ for column I, and $1 \mu \mathrm{g} / \mathrm{ml}$ for column II) at $40^{\circ} \mathrm{C}$ in the presence or the absence of $268 \mu \mathrm{M}$ NADPH. After $3 \mathrm{hr}$ of incubation, progesterone was quantified by radioimmunoassay as described in Materials and Methods.

\begin{tabular}{|c|c|c|c|c|c|}
\hline \multicolumn{4}{|c|}{ Addition to the incubation medium } & \multicolumn{2}{|c|}{ Progesterone contents $(\mathrm{ng} / \mathrm{m} l)$} \\
\hline & Homogenates & obtained from & Cofactor & I & II \\
\hline & & - & - & $109.2 \pm 12.8^{\mathrm{a} 1)}$ & $1038 \pm 47^{\mathrm{d}}$ \\
\hline F 1 & Theca layer & $(720 \mu \mathrm{g}$ protein $/ \mathrm{m} l)$ & - & $88.9 \pm 8.8^{\mathrm{ab}}$ & \\
\hline F 2 & Theca layer & $(720 \mu \mathrm{g}$ protein $/ \mathrm{m} l)$ & - & $83.4 \pm 7.8^{\mathrm{ab}}$ & \\
\hline F 3 & Theca layer & $(720 \mu \mathrm{g}$ protein $/ \mathrm{m} l)$ & - & $77.6 \pm 8.6^{b}$ & \\
\hline F 1 & Theca layer & $(720 \mu \mathrm{g}$ protein $/ \mathrm{m} l)$ & NADPH & $6.4 \pm 0.9^{c}$ & \\
\hline F 2 & Theca layer & $(720 \mu \mathrm{g}$ protein $/ \mathrm{m} l)$ & NADPH & $1.6 \pm 0.6^{c}$ & \\
\hline F 3 & Theca layer & $(720 \mu \mathrm{g}$ protein $/ \mathrm{m} l)$ & NADPH & $1.4 \pm 0.7^{c}$ & \\
\hline F 1 & Theca layer & $(72 \mu \mathrm{g}$ protein $/ \mathrm{ml})$ & NADPH & & $929 \pm 75^{d}$ \\
\hline F 2 & Theca layer & $(72 \mu \mathrm{g}$ protein $/ \mathrm{m} l)$ & NADPH & & $442 \pm 47^{\mathrm{e}}$ \\
\hline F 3 & Theca layer & $(72 \mu \mathrm{g}$ pratein $/ \mathrm{m} l)$ & NADPH & & $465 \pm 20^{\mathrm{e}}$ \\
\hline
\end{tabular}

1) mean \pm S.E. $(n=6)$ Means without a common superscript differ significantly $(P<0.05)$ from each other when analyzed by the $\mathrm{Q}$ method $^{20)}$.

of the theca layer was reduced to $72 \mu \mathrm{g} / \mathrm{ml}$, more than $50 \%$ of progesterone was metabolized in the incubation of the cell-free homogenates of the theca layers of F2 and F3, while those of F1 did not metabolize progesterone appreciably (Table 1). Fig. 3 shows the time courses of the progesterone metabolism by the cell-free homogenates of the theca layers of $\mathrm{F} 1$ and F3. The rate of decrease of progesterone was faster in the incubation with the cell-free homogenates of the theca layer of F3 than those of F1.

In the next experiment, the cell-free homogenates of the theca layers were incubated 


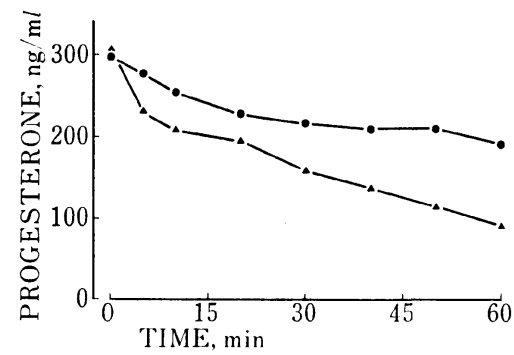

Fig. 3. Time course of decrease in progesterone by the cell-free homogenates of theca layer of the quail follicles. The cell-free homogenates $(30 \mu \mathrm{g}$ protein $/ \mathrm{m} l)$ of the theca layers of F $1(\bullet)$ and F $3(\boldsymbol{\Delta})$ were incubated with 300 $\mathrm{ng} / \mathrm{m} l$ of progesterone at $40^{\circ} \mathrm{C}$ in the presence of 268 $\mu \mathrm{M}$ NADPH.

Table 2. Effects of the cell-free homogenates of the theca layer on LH-stimulated progesterone production by the granulosa cells of $\mathrm{F} 1$

The cell-free homogenates of the theca layer were incubated with the granulosa cells of $\mathrm{F} 1$ and $2 \mu \mathrm{g} / \mathrm{ml}$ ovine $\mathrm{LH}$ at $40^{\circ} \mathrm{C}$ in the presence or the absence of $268 \mu \mathrm{M} \mathrm{NADPH}$. After $3 \mathrm{hr}$ of incubation, progesterone was quantified by radioimmunoassay as described in Materials and Methods.

\begin{tabular}{|c|c|c|c|}
\hline \multicolumn{3}{|c|}{ Addition to the incubation medium } & \multirow{2}{*}{ Progesterone contents $(\mathrm{ng} / \mathrm{m} l)$} \\
\hline Homogenates & s obtained from & Cofactor & \\
\hline & - & - & $92 \pm 8.1^{\text {de } 1)}$ \\
\hline F 1 Theca layer & $(720 \mu \mathrm{g}$ protein $/ \mathrm{m} l)$ & - & $144 \pm 3.2^{\mathrm{a} \mathrm{b}}$ \\
\hline F 2 Theca layer & $(720 \mu \mathrm{g}$ protein $/ \mathrm{m} l)$ & - & $160 \pm 8.2^{\mathrm{a}}$ \\
\hline F 3 Theca layer & $(720 \mu \mathrm{g}$ protein $/ \mathrm{m} l)$ & - & $142 \pm 1.5^{\mathrm{a} \mathrm{b}}$ \\
\hline F 1 Theca layer & $(72 \mu \mathrm{g}$ protein $/ \mathrm{m} l)$ & - & $98 \pm 2.3^{\mathrm{cd}}$ \\
\hline F 2 Theca layer & $(72 \mu \mathrm{g}$ protein $/ \mathrm{m} l)$ & - & $96 \pm 5.5^{\mathrm{d} \mathrm{e}}$ \\
\hline F 3 Theca layer & $(72 \mu \mathrm{g}$ protein $/ \mathrm{m} l)$ & - & $99 \pm 7.2^{\mathrm{cd}}$ \\
\hline F 1 Theca layer & $(720 \mu \mathrm{g}$ protein $/ \mathrm{m} l)$ & NADPH & $123 \pm 0.7^{\mathrm{bc}}$ \\
\hline F 2 Theca layer & $(720 \mu \mathrm{g}$ protein $/ \mathrm{m} l)$ & NADPH & $108 \pm 3.2^{\mathrm{cd}}$ \\
\hline F 3 Theca layer & $(720 \mu \mathrm{g}$ protein $/ \mathrm{m} l)$ & NADPH & $70 \pm 4.0^{\mathrm{e}}$ \\
\hline F 1 Theca layer & $(720 \mu \mathrm{g}$ protein $/ \mathrm{m} l)$ & NADPH & $37 \pm 5.1^{f}$ \\
\hline F 2 Theca layer & $(720 \mu \mathrm{g}$ protein $/ \mathrm{m} l)$ & NADPH & $22 \pm 0.1^{\mathrm{f}}$ \\
\hline F 3 Theca layer & $(720 \mu \mathrm{g}$ protein $/ \mathrm{m} l)$ & NADPH & $16 \pm 1.1^{\mathrm{f}}$ \\
\hline
\end{tabular}

1) mean \pm S.E. $(n=3)$

Means without a common superscript differ significantly $(P<0.05)$ from each other when analyzed by the $\mathrm{Q}$ method $^{20)}$.

with the granulosa cells of $\mathrm{F} 1$ in the presence of $\mathrm{LH}$, instead of progesterone as the source of the steroid. As shown in Table 2, the granulosa cells of F1 derived from $1 \mathrm{mg}$ wet weight of the tissue produced $92 \mathrm{ng} / \mathrm{ml}$ of progesterone after $3 \mathrm{hr}$ of incubation in the presence of $\mathrm{LH}$. When the cell-free homogenates $(72 \mu \mathrm{g}$ protein $/ \mathrm{ml})$ of the theca layers and NADPH were present during incubation, progesterone contents decreased. Moreover, this decrease was more prominent in the incubation with the theca later of less matured follicles, such as F2 and F3, than that of matured follicle. No such a decrease in progesterone con- 
tents was observed in the incubation without NADPH. When much concentrated cell-free homogenates $(720 \mu \mathrm{g}$ protein $/ \mathrm{ml}$ ) of the theca layers were added to the incubation mixture together with NADPH, the amounts of progesterone after $3 \mathrm{hr}$ of incubation were not decreased in the case of the theca layers of F1 and F2. Contrary, after the incubation with the cell-free homogenates of the theca layer of F1, progesterone contents increased. A slight decrease in progesterone was observed in the incubation with the cell-free homogenates of the theca layer of F3, but the degree of decrease was much smaller than in the incubation using more diluted cell-free homogenates. The increase in progesterone contents in the presence of the cell-free homogenates of the theca layers was markedly observed in the incubation without NADPH. In this case, however, no systematic tendencies in the effects were seen among the size of follicles.

\section{Discussion}

Our observations on the in vitro progesterone production in the intact follicle wall clearly demonstrate that only the follicle wall of $\mathrm{F} 1$ produces progesterone in response to $\mathrm{LH}$ and dibutyryl cyclic AMP. This is consistent with the in vivo findings of Dor et al. ${ }^{2)}$, who measured progesterone contents in the follicle wall of the Japanese quail at a 2-hr interval during the $24 \mathrm{hr}$ of the ovulatory cycle. They observed that progesterone contents started to increase simultaneously with the increase in serum LH concentration and reached a peak $2 \mathrm{hr}$ before the predicted ovulation of F1. Progesterone contents in the follicle walls of smaller follicles were always low and did not show any significant peak during the ovulatory cycle. A similar finding has been reported in the chicken follicle ${ }^{1,13,14}$. Moreover, the experiments of measurement of progesterone contents in follicular venous plasma during the ovulatory cycle of the hen also demonstrated that a preovulatory peak of progesterone exists only in the venous plasma from $\mathrm{F}^{3}{ }^{3}$, although a peak of $\mathrm{LH}$ concentration was detected in the venous plasma of each follicle.

On the other hand, experiments on the in vitro progesterone production of the isolated granulosa cells showed that the cells from smaller follicles (F2 and F3) produced signficant amounts of progesterone. However, these cells produced progesterone during $3 \mathrm{hr}$ of incubation without exogenous LH or dibutyryl cyclic AMP, while the cells of F1 produced comparable amounts of progesterone to the intact follicle wall did in response to $\mathrm{LH}$ and dibutyryl cyclic AMP. Recently, $\mathrm{C}_{A L B O}$ and $\mathrm{BAHR}^{15)}$ reported that the adenylate cyclase activity in the chicken granulosa cells of the small follicles was enhanced by follicle-stimulating hormone (FSH). Serum FSH concentration during the ovulatory cycle of the hen showed a peak 11 to $14 \mathrm{hr}$ before ovulation ${ }^{16,17}$. Since the granulosa cells used in the present experiments were isolated from birds 9 to $10 \mathrm{hr}$ before the predicted ovulation of $\mathrm{F} 1$, the progesterone production in the cells of F2 and F3 during in vitro incubation without $\mathrm{LH}$ or dibutyryl cyclic AMP might be due to the endogenous FSH or cyclic AMP.

The reason why progesterone production was not detected in the incubation of the follicle walls of F2 and F3 in spite of the ability of the granulosa cells to produce progesterone was partly explained by the present investigation on the metabolism of progesterone in another component of the follicle wall, the theca layer. HuAnG, KaO, and NaLBandov ${ }^{5)}$ also 
reported a depression in progesterone production of the granulosa cells by the co-incubation with the theca cells. As shown in Table 1 and Figure 3 in the present experiments, the cell-free homogenates of F2 and F3 have the ability to metabolize more progesterone than those of F1. Metabolic pattern of progesterone in avian follicles has not been well studied, but it was reported that the concentration of testosterone and estradiol-17 $\beta$ in the follicle wall was higher in the small follicles than $\mathrm{F}^{1,2,13,14}$. Indeed, WANG and $\mathrm{BAHR}^{18)}$ reported the in vitro secretion of estradiol-17 $\beta$ by the theca cells of F2 and F3 of the hen. Therefore, progesterone synthesized in the granulosa cells of F2 and F3 may be transferred to the theca layer and used as substrates for testosterone and estradiol- $17 \beta$ productions. NAKAmURA et al. ${ }^{19}$ ) reported that the activity of $17 \beta$-hydroxylase, one of the enzymes involved in the conversion of progesterone to testosterone, was higher in $\mathrm{F} 2$ than in F1.

The metabolism of progesterone may not be sole factor affected on the amount of progesterone production in the quail follicles. Unexpectedly, in the present study the addition of the cell-free homogenates of the theca layer augmented the progesterone production of the granulosa cells of F1 (Table 2). This is not due to contamination of serum nor the increased protein concentration in the incubation medium (data not shown). Further experiments on this augmenting factor are being carried out.

\section{Summary}

During $3 \mathrm{hr}$ of incubation, the production of progesterone in the follicle wall from the largest preovulatory follicle (F1) of the Japanese quail was stimulated by ovine LH or dibutyryl cyclic AMP. The follicle walls from the second largest and the third largest follicles (F2 and F3) did not produce appreciable amounts of progesterone, while the granulosa cells isolated from these follicles produced significant amounts of progesterone. By incubating progesterone with the cell-free homogenates of the theca layer in the presence of NADPH, it was clarified that the metabolic rates of progesterone in the theca layer of F2 and F3 were higher than that of F1. These results suggested that in the quail follicles, progesterone is produced in the granulosa layer but the theca layers of the small follicles metabolize progesterone, so that only $\mathrm{F} 1$ secretes progesterone.

\section{Acknowledgement}

The authors are indepted to Mr. Toichiro Kondo in this laboratory for his assistance during this work.

\section{References}

1) Shahabi, N. A., H. W. Norton and A. V. Nalbandov (1975) Steroid levels in follicles and the plasma of hens during the ovulatory cycle: Endocrinology 96: 962-968.

2) Doi, o., T. Takai, T. Nakamura and Y. TAnabe (1980) Changes in the pituitary and plasma LH, plasma and follicular progesterone and estradiol, and plasma testosterone and estrone concertrations during the ovulatory cycle of the quail (Coturnix coturnix japonica): Gen. Comp. Endocrinol. 41: $156-163$.

3) Etches, R. J., F. CROze and C.E. Duke (1981) Plasma concentrations of luteinizing hormone, progesterone, testosterone and estradiol in follicular and peripheral venous plasma during the ovulation cycle of the hen: Adv. Physiol. Sci. 33: 89-98.

4) Tojo, H. and T. M. Huston (1981) Effects of steroid blockers on LH-induced ovulation in the domestic fowl, Gallus domesticus: J. Reprod. Fert. 61: 381-386. 
5) Huang, E. S., K. J. Kao and A. V. Nalbandov (1979) Synthesis of sex steroids by cellular components of chicken follicles: Biol. Reprod. 20: 454-461.

6) Hammond, R. W., W. H. Burke and F. Hertelendy (1981) Influence of follicular maturation on progesterone release in chicken granulosa cells in response to turkey and ovine gonadotropins: Biol. Reprod. 24: 1048-1055.

7) Wells, J. W., A. B. Gilbert and J. Culbert (1980) Effect of luteinizing hormone on progesterone secretion in vitro by the granulosa cells of the domestic fowl (Gallus domesticus): J. Endocrinol. 84: $249-254$.

8) Tanabe, Y. (1977) Differences in the endocrine mechanism of ovulation of the domestic fowl and the Japanese quail: Proc. 1st Int. Symp. Avian Endocrinol. Calcutta, 68-70.

9) Gulati, D. P., T. Nakamura and Y. Tanabe (1981) Diurnal variations in plasma LH, progesterone, testosterone, estradiol, and estrone in the Japanese quail: Poult. Sci. 60: 668-673.

10) Gilbert, A. B., A. J. Evans, M. M. Perry and M. H. Davidson (1977) A method for separating the granulosa cells, the basal lamina and the theca of the preovulatory ovarian follicle of the domestic fowl (Gallus domesticus): J. Reprod. Fert. 50: 179-181.

11) Kotosai, K. (1982) Periodic changes in steroidogenesis of rapidly growing ovarian follicles of Japanese quail: Master's Thesis, The graduate school, Universty of Tokyo.

12) Lowry, O. H., N. J. Rosebrough, A. L. Farr and R. J. Randall (1951) Protein measurement with the Folin phenol reagent: J. Biol. Chem. 193: 265-275.

13) Shahabl, N. A., J. M. Bahr and A. V. Nalbandov (1975) Effect of LH injection on plasma and follicular steroids in the chicken: Endocrinology 96: 969-972.

14) Bahr, J. M., S. C. Wang, M. Y. Huang and F. O. Calvo (1983) Steroid concentrations in isolated theca and granulosa layers of preovulatory follicles during the ovulatory cycle of the domestic hen: Biol. Reprod. 29: 326-334.

15) Calvo, F. O. and J. M. Bahr (1983) Adenylyl cyclase system of the small preovulatory follicles of the domestic hen: Responsiveness to follicle-stimulating hormone and luteinizing hormone: Biol. Reprod. 29: 542-547.

16) Imai, K. and A. V. Nalbandov (1971) Changes in FSH activity of anterior pituitary glands and of blood plasma during the laying cycle of the hen: Endocrinology 88: 1465-1470.

17) Scanes, C. G., P. M. M. Godjen and P. J. Sharp (1977) An homologous radioimmunoassay for chicken follicle-stimulating hormone: Observations on the ovulatory cycle: J. Endocrinol. 73: 473-481.

18) Wang S. C. and J. M. BAHR (1983) Estradiol secretion by theca cells of the domestic hen during the ovulatory cycle: Biol. Reprod. 28: 618-624.

19) Nakamura, T., Y. Tanabe and H. Hirano (1979) Progesterone and estradiol levels in folliles and the in vitro metabolism of steroid hormones by hen during the ovulatory cycle: Japan. Poult. Sci. 16: $15-25$.

20) Snedecor, G. W. and W. E. Cochran (1980) Statistical Methods: 7th ed. the Iowa State University Press, Ames, Iowa, U. S. A. 


\title{
ウズラ卵胞の顆粒膜と卵胞膜がプロゲステロン 生合成におよぼす役割
}

\author{
森誠・河本移・正田陽一 \\ 東京大学 農学部 家畜育種学教室 \\ 東京都文京区 $\bar{\top} 113$
}

排卵周期中の家禽の卵巣にはさまざまな大きさの卵胞 が混在しているが，1日1個の排卵は最大卵胞（F1）か らのみおこなわれる。F1 は LH に反応してプロゲステ ロンを生成分泌することが知られているが，なぜ F1 の みが LH に反応し，その他の卵胞は反応しないのだろら か。本研究はこの疑問に答えるために，LH の影響を受 ける前, すなわち F1 の排卵予定時刻の 9 10 時間前に ウズラを殺し, 大きい順に 3 個の卵胞 (F1, F2, F3) を 摘出してそれらのブロゲステロン生合成能をインビトロ で比較検討した。

まず卵胞からの卵黄のみを取り除いた卵胞壁をクレブ ス・リンガー・HEPES 培養液中で 40 度, 3 時間インキ ュベートし，その後組織を培養液とともにホモゲナイズ してェーテルでプロゲステロンを抽出し, ラジオイムノ アッセイで定量した。その結果, 培養液に $2 \mu \mathrm{g} / \mathrm{ml}$ の羊 $\mathrm{LH}$ または $1 \mathrm{mM}$ のジブチリルサイクリック AMP を 添加すると, F1 の卵胞壁のプロゲステロン生成量は影著 に増加した。一方 F2 F 3 から得た卵胞壁ではこのよ らな効果はみられず, プロゲステロン量はインキュベー ション前とかわらなかった。卵胞壁から顆粒膜のみを単 離し同様の実験をおこない，プロゲステロン生成量を卵 胞あたりで比較したところ，F1 では卵胞壁を用いた場 合と結果は全く同じで, LH やジブチリルサイクリック AMP に反応してプロゲステロンを生成するのは顆粒膜
であることがわかった。しかし卵胞壁を用いた場合には プロダステロンの生成が認められなかった F2 F F3で は，顆粒膜細胞を用いるとプロゲステロンの生成が認め られるようになった。ただしこの場合は，単に顆粒膜細 胞を培着液中でインキュベートするだけでプロゲステロ ソの生成がおこり, LH やジブチリルサイクリック AMP を添加しても効果はなかった。

以上の結果は, F2 F 3 の顆粒膜細胞はプロゲステ ロンを生成しているのだが，卵胞壁のもら一つの構成因 子である卵胞膜がそれを代謝してしまうためにこれらの 卵胞ではあたかもプロゲステロンが生成されていないよ らにみえるのであろら事を強く示唆している。そこで F1, F2, F3 の卵胞膜のホモジネートを NADPH の存 在下でプロゲステロンとインキュベートすることによっ て代謝能を調べたところ，確かに F2 F F の卵胞膜は プロダステロン代謝能が F1 よりも高いことが明らかと なった。

$\mathrm{F} 2$ や F3 で生成されたブロゲステロンは颃そらく卵 胞膜でテストステロンやエストラジオールに代謝され， F1 ではこれらのステロイドホルモンへの代謝が少いた めにプロゲステロンのままで放出されていることが推察 された。

（家禽会誌，21，206～214，1984） 